\title{
COVID-19 Employment Crisis in Vietnam: Global Issue, National Solutions
}

\author{
Huong T. T. Nguyen ${ }^{1}$, Tham T. Nguyen ${ }^{1}$, Vu A. T. Dam ${ }^{1}$, Long H. Nguyen ${ }^{2}$, Giang T. Vu ${ }^{3}$, \\ Huong L. T. Nguyen ${ }^{4,5 *}$, Hien T. Nguyen ${ }^{4,5}$ and Huong T. Le ${ }^{1}$ \\ ${ }^{1}$ School of Preventive Medicine and Public Health, Hanoi Medical University, Hanoi, Vietnam, ${ }^{2}$ Vietnam National University \\ School of Medicine and Pharmacy, Vietnam National University, Hanoi, Vietnam, ${ }^{3}$ Center of Excellence in Evidence-Based \\ Medicine, Nguyen Tat Thanh University, Ho Chi Minh City, Vietnam, ${ }^{4}$ Institute for Global Health Innovations, Duy Tan \\ University, Da Nang, Vietnam, ${ }^{5}$ Faculty of Nursing, Duy Tan University, Da Nang, Vietnam
}

Keywords: SARS-CoV-2, economy, unemployment, solutions, Vietnam, COVID-19

Since the first case being reported in January 23, Vietnam has 911 confirmed cases (430 recovered and 460 actives) with 21 fatalities (1). A large number of people being infected and died from the disease, unprecedented measures taken by Vietnam government to curb the infection rate-from social distancing to locking down which involve business closing, have significantly affected economy, especially in terms of employment. Specifically, the groups of industries such as: Aviation services; Hotel/Food and Beverage Service and other services when revenue dramatically decreased about 50 and 23.6\%, respectively, compared to the same period last year (2). According to the General Statistics Office of Vietnam, in the first 6 months of 2020, the number of enterprises suspending business for a definite time was 29.2 thousand, increasing by $38.2 \%$ over the same period last year, while 19.6 thousand enterprises stopped and focused mainly on the service sector. There were 897.5 thousand people losing jobs while the number of unemployed people was at 1.3 million, an increase of 123.9 thousand, making the unemployment rate reaching the highest point in 10 years (3). In which, the groups of non-working age groups, female workers, unskilled workers, migrant workers, and informal workers are the most vulnerable groups caused by pandemic $(4,5)$. In particularly, the female workers group, the unemployment rate was about $2.9 \%$, higher than that of men and increased sharply over the same period last year (3) and for the informal workers-workers without labor contracts, unemployment insurance (4), there was $72 \%$ of those in the group affected by the COVID-19 pandemic when they mainly focused on Industry groups suffered the most damage: F\&B, Hotel, logistic, etc. (6-8). In addition, domestic migrant workers, which account for $13.6 \%$ of the total population, often work in the informal economy without a work contract and without access to social protection regimes (8).

However, one thing is clear. With various forms of lockdowns and social distancing, Vietnam are facing a really difficult time. Out of 51.8 million employed workers in the second quarter of this year, 30.8 million people were affected by epidemics, of which 2.4 million workers lost their jobs, the national unemployment rate increase (7). In which, about 17.6 million people suffer income loss due to disease, accounting for $57.3 \%$ of the total affected people (9). COVID-19 pandemic directly impact employment. The number of employees in several occupations decreased a sharp fall compared to the last year as follows: unskilled group reduced by nearly 1.5 million workers, equivalent to nearly $8 \%$; the group of craft and related trades workers decreased by 515 thousand persons, equivalent to a fall of $6.6 \%$; the number of employees in the middle-level qualification group fell by 322 thousand persons, equivalent to a decrease of $16.5 \%$ (6). The General statistics office of Vietnam reported that the average monthly income of workers decreased for the first in 5 years. Especially, the deepest decrease in monthly average income in the 2nd quarter of 2020 compared to the same period last year as follows "Arts, entertainment and recreation," 
"accommodation and catering service." "transportation and storage" "wholesale and retail trade and repair of motor vehicles and motorcycles" down 19.2, 18.3, 12.8, and 9.1\%, respectively (6). With unemployment rising and income per labor reduction has led to the economic growth rate only reached the level of $1.81 \%$ in the first 6 months of the year-the lowest figure recorded in the whole period 2011-2020 (10). The COVID-19 pandemic caused the income of many Vietnamese households to decrease by $70 \%$ (11). In addition, household income deepest decrease the most due to the Covid-19 epidemic, recorded in April 2020, when only 29.7\% compared to December 2019. This figure to May 2020 is $51.1 \%$ (11). Children can also be affected by loss of a job or income loss from their parents (8). More than 21 million students in Viet Nam being affected by school closures (12). It is estimated that more than 1 million childrens aged 5-17 years are engaged in child labor, this children were face to work longer hours or in worse conditions (13). During the COVID-19 pandemic, dropouts, malnutrition, labor exploitation, and child labor can increase dramatically. This lead to serious consequences, especially for the development of the workforce.

With the negative impact of COVID-19 pandemic, Vietnam's economic growth in 2020 also was decreased by about $4 \%$ compared to last year $(14,15)$. However, the Vietnam government had several solutions manage the fiscal deficit for solving immediate problems such as focus on effectively implementing domestic stimulus, use the savings from falling international oil prices to curb the crisis, earn funding from the World Bank WB and the International Monetary Fund, etc. $(16,17)$. Besides, economic recovery solutions such as promoting production, business, socio-economic development are also offered in three main contents: General solutions; urgent solutions; and Long-term solutions (Figure 1). Firstly, according to The Politburo on the policy of overcoming the impact of the COVID-19 pandemic to improve and develop the economy, the Government would provide support in the form of (1) to make the most of the domestic market, at the same time to prevent and respond to instabilities from outside; (2) to develop a favorable and attractive business environment, suitable to new trends, and have regional and international competitiveness; (3) to identify opportunities and challenges to take advantage of solutions, transform opportunities, and challenges into motivation on economic growth (18). Secondly, for urgent solutions for solving immediate problems consist of (1) extension for payment of tax and other duties (social insurance, trade union fees, etc.); (2) financial assistance through policies that require lending institutions to reduce lending rate, facilitate debt rescheduling, provide liquidity for businesses affected by COVID-19; (3) monetary allowance and $0 \%$ interest loan for those having their employment affected by the pandemic; and (4) promoting of

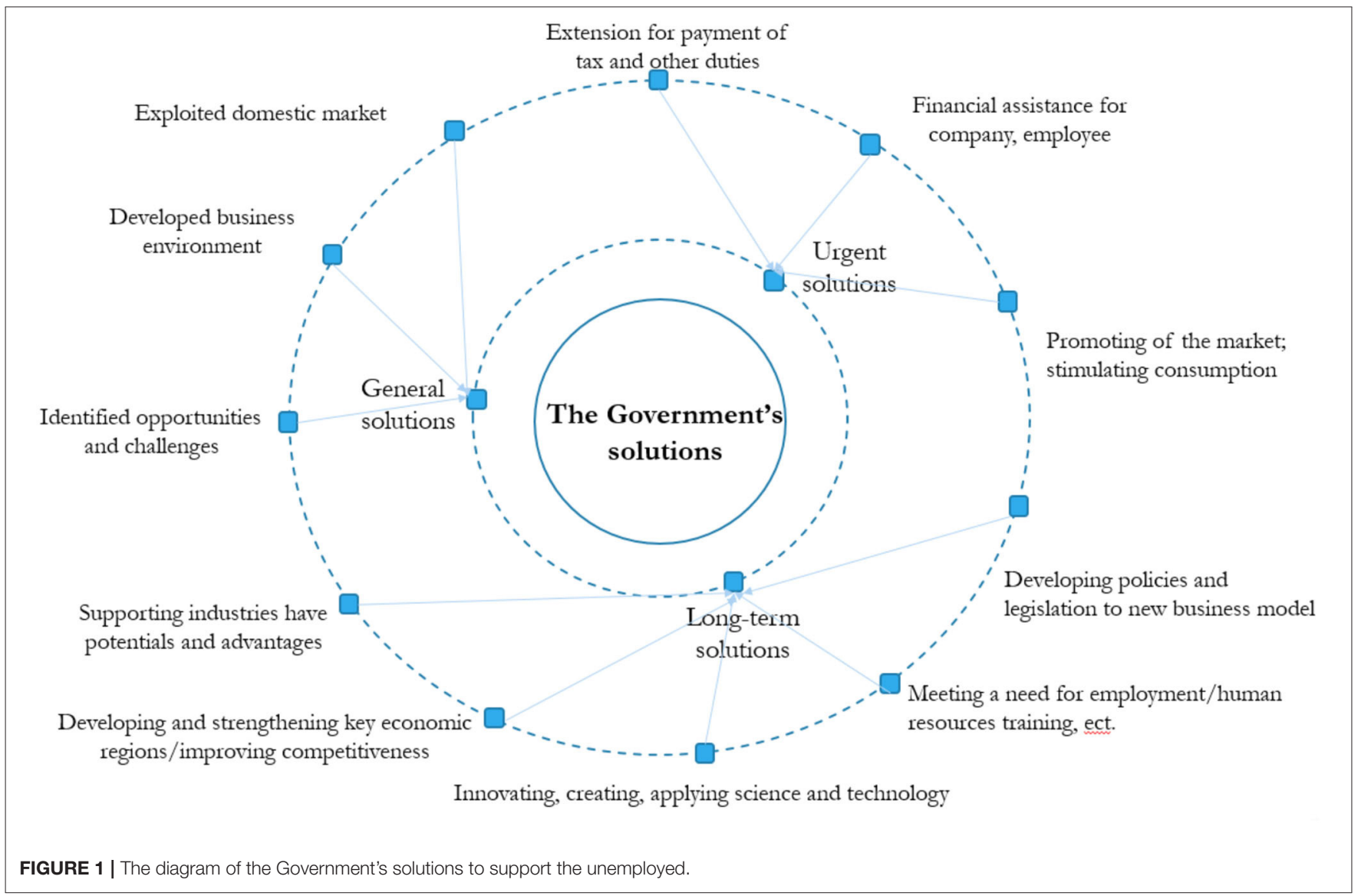


the domestic market and stimulating domestic consumption (19-21). In addition, some solutions such as Stop paying social insurance, stop paying premiums, reduce union fee by $50 \%$ and reduce $15 \%$ land rent reduction policy should be applied to all businesses because most of the businesses are affected, possibly operating but facing many difficulties (according to Resolution 84). Stabilize electricity and water prices of enterprises and eliminate monopoly prices in this field. A number of policies on banking and finance such as solutions to support liquidity, debt rescheduling, and debt group retention; Reduce lending interest rates; Extending credit guarantee measures so that small, medium and micro-enterprises, business households can borrow capital (22). Specifically, the Vietnamese government has introduced a US \$ 2.7 billion relief fund to support all workers affected by the COVID-19 pandemic in Vietnam. In particular, this bailout package focus on support for businesses in difficulty, workers deeply affected by income, and vulnerable people who are not supported to access many existing social security networks within 3 months (April, May, and June) with different levels of support for each group of workers (23). Finally, for longterm solution, Vietnam's government have strategies include (1) developing policies and legislation to facilitate new business models; (2) economic restructuring and support potential and advantageous industries; (3) improving competitiveness and support businesses/enterprise; (4) innovating, creating, applying science and technology; (5) meeting a need of social security, employment, and human resources training; and (6) developing and strengthening key economic regions. Vietnam has drastically rectified the job crisis related to COVID-19 and most importantly, minimizes the damage that affects businesses and employees. Therefore, it is important to ensured that the socio-economic policy is built based on three aspects: the Government, employers, and workers. Vietnam has dealt with the job crisis related to COVID-19 drastically. It is important to minimize damage affecting businesses and workers. This is an important time to ensure that the socioeconomic policy is built in an inclusive manner based on government, employers, and workers. These difficult times provide an opportunity for Vietnam to establish a more inclusive growth platform.

In COVID-19 pandemic, Vietnam faces many opportunities and challenges for the businesses as well as workers in the process of adapting to the new economic model. Generally, the business market suffered heavy losses due to the crisis, which led to an inordinate increase in the unemployment rate (2.73\%) (7). In terms of urgent period, there are several challenges for the economy when market demand decreased and becomes more competitive due to some industries are strongly affected such as the GDP of export industry and services decreased about 8.45$9.67 \%$ (7). This also leads to the highest unemployment rate in the 10 years and a concentration of a large number of vulnerable labor (6). Therefore, business owners need to grasp the demand for their products/services as well as the availability of labor force during and after the pandemic, to identify new opportunities and implement timely business model transformation. Additionally, it requires the Government and business to offer several measures to support workers especially the vulnerable group: financial support and job hunting $(23,24)$. Besides the challenges, some policies have been introduced to support businesses to maintain business, retain employees, and minimize employee layoffs (25). Specifically, businesses are entitled to tax extension, tax reduction, and financial support (22). Therefore, the risk of unemployment and income reductions can be reduced, especially in sectors such as services and import-export which are most affected (26). In the long term, businesses can be affected for a long time and the business market in Vietnam needs time to recover. Key sectors such as service and import-export still suffer due to the disease's complicated evolution of the epidemic and the mandatory quarantine policy upon entry in Vietnam (According to Official dispatch 1440 of the National steering committee for Disease Control and Prevention COVID-19). Vietnam implemented a social division from April 1 to April 23 (According to Directive 15 of the National steering committee for Disease Control and Prevention COVID-19). This lead to several opportunities and challenges for companies and employees. Specifically, businesses need to develop existing markets and exploit new markets such as developing the domestic market when import-export is limited, and prioritize the development of the online transaction market. From there, it is possible to form the habit of prioritizing local consumption for Vietnamese customers. Development of the digital era and technological revolution 4.0 is the big chance for all enterprise/business. It contributes to improving production capacity, promoting products, creating potential opportunities in implementing online sales services which are a strong development model during the epidemic. Finally, it is important that businesses proactively come up with the right solutions for themselves to adapt to new markets and employees also actively seek opportunities, hone their skills to adapt to new business model of the market.

\section{AUTHOR CONTRIBUTIONS}

HTTN, TTN, VATD, LHN, GTV, and HTL: conceptualization. HTTN, TTN, and VATD: writing original draft. HTTN, TTN, VATD, LHN, GTV, HTL, HTN, and HLTN: writing, review and editing. LHN and GTV: project administration. All authors contributed to the article and approved the submitted version.

\section{FUNDING}

Research was supported by Vingroup Innovation Foundation (VINIF) in project code VINIF. 2020.COVID-19.DA03. 


\section{REFERENCES}

1. Ministry of Health. COVID-19 Disease Status Statistics 2020. (2020). Available online at: https://ncov.moh.gov.vn/ (accessed August 14, 2020).

2. Tram B. Revenue Fell 50\%, 2020 Being the Worst Year in Aviation History: 2020. (2020). Available online at: https://forbesvietnam.com.vn/tin-cap-nhat/ doanh-thu-giam-50-2020-la-nam-toi-te-nhat-trong-lich-su-hang-khong11237.html (accessed August 14, 2020).

3. Rationale and design of a randomized clinical trial on prevention of stroke in isolated systolic hypertension. The systolic hypertension in the elderly program (SHEP) cooperative research group. J Clin Epidemiol. (1988) 41:1197-208. doi: 10.1016/0895-4356(88)90024-8

4. Hao S. Risk Reduction for Informal Workers: Must Start With Labor Policy. (2020). Available online at: https://baodantoc.vn/giam-rui-ro-cho-lao-dongphi-chinh-thuc-phai-bat-dau-tu-chinh-sach-ve-lao-dong-1586875740402. htm (accessed August 14, 2020).

5. To H. Recovery of Production, Business, and Job Keeping for Workers: 2020. (2020). Available online at: https://nhandan.com.vn/tin-tuc-kinh-te/ phuc-hoi-san-xuat-kinh-doanh-giu-viec-lam-cho-nguoi-lao-dong-609247/ (accessed August 13, 2020).

6. General Statistics Office Report on the Impact of COVID-19 Epidemic on Labor and Employment in Vietnam (2020). Available online at: https://www. gso.gov.vn/du-lieu-va-so-lieu-thong-ke/2020/10/bao-cao-tac-dong-cuadich-covid-19-den-tinh-hinh-lao-dong-viec-lam-tai-viet-nam-quy-iii2020/ (accessed August 18, 2020).

7. General Statistics Office of Vietnam. Report on the Impact of the Covid-19 on Labour and Eployment Situation in Vietnam. (2020).

8. International Labour Organization. The Time Has Come to Prove that Vietnam Excels in Dealing With Economic Challenges as Well. (2020). Available online at: https://www.ilo.org/hanoi/Informationresources/Publicinformation/ comments-and-analysis/WCMS_741637/lang--vi/index.htm (accessed April $15,2020)$.

9. General Statistics Office of Vietnam. Press Release Labor and Employment Situation in Quarter II and the First 6 Months of 2020. (2020) 07/10.

10. Nguyen D. Vietnam experiences highest unemployment for a decade due to Covid-19. Vietnam Insider. (2020). Available online at: https:/vietnaminsider.vn/vietnam-experiences-highestunemployment-for-a-decade-due-to-covid-19/ (accessed August 13, 2020)

11. Linh H. The COVID-19 pandemic caused the income of many Vietnamese households to decrease by $70 \%$. Tap chi tai chinh. (2020). Available online at: http://tapchitaichinh.vn/tai-chinh-kinh-doanh/dich-covid19-khien-thunhap-cua-nhieu-ho-gia-dinh-viet-nam-giam-toi-70-325853.html

12. Vu L. Placing Children at the Heart of Viet Nam's COVID-19 Response. (2020). Available online at: https://www.unicef.org/vietnam/vi/nh?ng-câu-chuy?n/ dua-tr?-em-vào-v?-trí-tr?ng-tâm-trong-?ng-phó-v?i-d?ch-covid-19-t?i-vi? t-nam (accessed April 30, 2020).

13. Anh PP. World Day Against Child Labour 2020: Viet Nam Joins Global Campaign to Confront Intensified Risk of Child Labour Resulting From COVID19. (2020). Available online at: unicef.org/vietnam/press-releases/worldday-against-child-labour-2020-viet-nam-joins-global-campaign-confront (accessed December 06, 2020).

14. Ministry of Finance GDP in the First 6 Months of 2020 Will Reach the Growth Rate of 1.81\%. (2020). Available online at: http://tapchitaichinh.vn/su-kien-noi-bat/gdp-6-thang-dau-nam2020-dat-muc-tang-truong-181-324929.html (accessed August $25,2020)$.
15. General Statistics Office. Press Release on the Socio-Economic Situation in the Fourth Quarter and 2019: 2019. (2020). Available online at: https:// www.gso.gov.vn/default.aspx?tabid=382\&idmid=2\&ItemID=19453 (accessed August 25, 2020).

16. Hinh DT. Some Solutions for Vietnam's Economy During the Covid-19 Pandemic. (2020). Available online at: https://www.bbc.com/vietnamese/ business- 52254390 (accessed November 04, 2020).

17. Thoa HT. Fiscal Solution Dealing With Covid-19. State Bank of Vietnam (2020)

18. Ministry of Health. Conclusion of the Politburo on the Policy of Overcoming the Impact of the COVID-19 Pandemic to Restore and Develop the Economy: 2020. (2020). Available online at: https://ncov.moh.gov.vn/web/guest/-/ketluan-cua-bo-chinh-tri-ve-chu-truong-khac-phuc-tac-ong-cua-ai-dichcovid-19-e-phuc-hoi-va-phat-trien-nen-kinh-te (accessed August 16, 2020).

19. Nickbakhsh S, Ho A, Marques DFP, McMenamin J, Gunson RN, Murcia PR. Epidemiology of seasonal coronaviruses: establishing the context for the emergence of coronavirus disease 2019. J Infect Dis. (2020) 222:17-25. doi: 10.1093/infdis/jiaa185

20. The Vinh. More than 30 Million Workers Were Affected by the Disease, Unemployment Increased: 2020. (2020). Available online at: https://tuoitre.vn/ news-20200710104857698.htm (accessed July 28, 2020).

21. Bao T. Economics During Covid-19 Period: 'Vietnam Do Not Expect Eagles': 2020. (2020). Available online at: https://www.thoibao1000.de/blog/2020/ 07/14/economics-during-covid-19-period-vietnam-do-not-expect-eagles/ (accessed July 28, 2020).

22. Chinh H. A Series of Solutions to Support Businesses: The Socialist Republic of Vietnam Online Newpaper of the Government. (2020). Available online at: http://baochinhphu.vn/Thi-truong/Hang-loat-giai-phap-ho-tro-doanhnghiep/399631.vgp (accessed February 07, 2020).

23. Ministry of Labour WiaSA. The Government Raised the Social Security Package to 62 Trillion VND, Supporting About 20 Million People in Need Due to Covid19: 2020. (2020). Available online at: http://www.molisa.gov.vn/Pages/tintuc/ chitiet.aspx?tintucID=222479 (accessed August 25, 2020).

24. Manh H. Reducing the Impact of Covid-19 on Vulnerable Groups in Vietnam: 2020. (2020). Available online at: https://dantri.com.vn/an-sinh/giamtac-dong-cua-covid-19-len-cac-nhom-de-bi-ton-thuong-tai-viet-nam20200610160144420.htm (accessed August 14, 2020).

25. International Labour Organization. Viet Nam Can Well Address Labour Market Challenges: 2020. (2020). Available online at: https://www.ilo.org/ hanoi/Informationresources/Publicinformation/comments-and-analysis/ WCMS_741638/lang--en/index.htm (accessed January 09, 2020).

26. The International Labour Organization. Viet Nam Can Well Address Labour Market Challenges. (2020). Available online at: https://ilo.org/hanoi/ Informationresources/Publicinformation/comments-and-analysis/WCMS_ 741638/lang--en/index.htm (accessed April 15, 2020).

Conflict of Interest: The authors declare that the research was conducted in the absence of any commercial or financial relationships that could be construed as a potential conflict of interest.

Copyright (c) 2020 Nguyen, Nguyen, Dam, Nguyen, Vu, Nguyen, Nguyen and Le. This is an open-access article distributed under the terms of the Creative Commons Attribution License (CC BY). The use, distribution or reproduction in other forums is permitted, provided the original author(s) and the copyright owner(s) are credited and that the original publication in this journal is cited, in accordance with accepted academic practice. No use, distribution or reproduction is permitted which does not comply with these terms. 